\title{
Synergistic effect of magnetic field and nanocomposite pour point depressant on the yield stress of waxy model oil
}

\author{
Hui-Rong Huang ${ }^{1} \cdot$ Wei Wang $^{1} \cdot$ Ze-Heng Peng ${ }^{1} \cdot \mathrm{Kai}_{\mathrm{Li}}{ }^{1}$ - Yan-Fen Ding ${ }^{2} \cdot$ Wei-Jie Yu ${ }^{1}$. Dong-Ying Gan ${ }^{1}$. \\ Chuan-Shuo Wang ${ }^{1} \cdot$ Yi-Han Xue ${ }^{1} \cdot$ Jing Gong ${ }^{1}$
}

Received: 17 September 2019 / Published online: 3 February 2020

(c) The Author(s) 2020

\begin{abstract}
Yield stress, as the key parameter to characterize the network strength of waxy oil, is important to the petroleum pipeline safety. Reducing the yield stress of waxy oil is of great significance for flow assurance. In this study, the effect of alternating magnetic field (intensity, frequency) on the yield stress of a waxy model oil with nanocomposite pour point depressant (NPPD) is systematically investigated. An optimum magnetic field intensity and frequency is found for the reduction in yield stress. When adding with NPPD, the heterogeneous nucleation of NPPD contributes to the reduction in yield stress for waxy model oil. Interestingly, the magnetic field is helpful for the modification of yield stress at a lower frequency and intensity before the optimal value; however, the modification is found to be weakened when the magnetic field is further increased after the optimal value. Possible explanation is proposed that the aggregation morphology of wax crystal would be altered and results in the release of wrapped oil phase from the network structure under the magnetic field.
\end{abstract}

Keywords Magnetic field $\cdot$ Nanocomposite $\cdot$ Yield stress $\cdot$ Waxy model oil

\section{Introduction}

Wax components in crude oil result in complex precipitation and crystallization behavior (Bai et al. 2019; Guo et al. 2004; Ganeeva et al. 2016; Hassanzadeh et al. 2018; Li et al. 2018; Lim et al. 2018; Wang et al. 2019; Zhang et al. 2013). In lowtemperature environment (e.g., deep water, polar region), the precipitated wax crystal forms three-dimensional network and may cause serious flow assurance problem such

Edited by Xiu-Qiu Peng

Wei Wang

w.wang@cup.edu.cn

$\triangle$ Jing Gong

ydgj@cup.edu.cn

1 Beijing Key Laboratory of Urban Oil and Gas Distribution Technology, MOE Key Laboratory of Petroleum

Engineering, National Engineering Laboratory for Pipeline Safety, China University of Petroleum, Beijing 102249, People's Republic of China

2 Beijing National Laboratory for Molecular Sciences, Key Laboratory of Engineering Plastics, Institute of Chemistry, Chinese Academy of Sciences, Beijing 100190,

People's Republic of China as coagulation, blockage and even rupture during pipeline transportation (Chevallier et al. 2000; Pechook et al. 2016; Visintin et al. 2005). Different chemical and physical methods are considered to modify the crystallization of crude oil (Ashbaugh et al. 2002; Castro and Vazquez 2008; Deshmukh and Bharambe 2008; Yang et al. 2019). Based on copolymerization and chemical grafting, pour point depressant (PPD) such as ethylene-vinyl acetate copolymers (EVA), acrylic acid ester polymers and styrene-maleic anhydride-acrylic acid alcohol ester copolymers (Binks et al. 2015; Castro and Vazquez 2011; Deshmukh and Bharambe 2014; Huang et al. 2013; Jun et al. 2010; Li et al. 2012; Liu et al. 2015; Soni et al. 2008; Soni et al. 2010; Xu et al. 2013) are synthesized; however, the fluidity of modified crude oil might deteriorate when temperature rises due to its instability (Soni et al. 2008).

In recent years, nanoparticle is selected to develop nanocomposite pour point depressant (NPPD) (AlSabagh et al. 2016; Gao et al. 2017; He et al. 2016; Huang et al. 2018, 2019; Norrman et al. 2016; Song et al. 2016; Tu et al. 2018; Yang et al. 2017; Yao et al. 2018; Zhao et al. 2018). Since the surface effect generated in nanometer dimension, nanoparticle possesses unique physical-chemical properties and has aroused tremendous attention in synthesizing various 
function materials (Guo et al. 2004; Ganeeva et al. 2016; Li et al. 2018; Lim et al. 2018; Zhang et al. 2013). Research on NPPD's synthesis and application has been conducted in the modification of wax crystallization (AlSabagh et al. 2016; He et al. 2016; Huang et al. 2019; Tu et al. 2018). Benefit from the specific lamellar structure and good dispersibility of nanoparticle, NPPD is prepared by blending of organic modified montmorillonite layer and different polymers (AlSabagh et al. 2016; Gao et al. 2017; He et al. 2016; Huang et al. 2018, 2019), which demonstrates better modification compared to traditional PPDs in reducing pour point and bulk phase viscosity. Meanwhile, organic modified silica nanoparticle is applied to prepare NPPD which demonstrates obvious improvement in the waxy oil fluidity (Norrman et al. 2016; Song et al. 2016). In addition, the graphene oxide and attapulgite are introduced into the development of NPPD and gained good achievement (Tu et al. 2018; Zhao et al. 2018).

Physical methods, as electrical or magnetic, are widely investigated (Bacri et al. 1995; Du et al. 2018; MartínezPalou et al. 2011; Ma et al. 2017; Tao et al. 2014). Both the electrical and magnetic treatments can depress the viscosity of waxy crude oil (Martínez-Palou et al. 2011). Under the electric field, it is revealed that the aggregation of suspended crystal particles into chains should be responsible for the weakness of crystal network (Tao et al. 2014). Similarly, the suspended crystal particles aggregate and lead to the decrease in waxy crude oil viscosity when applying a pulsed magnetic field (Rosensweig 1996; Tao and Xu 2006). However, the modification effect of magnetic field is selective which is not only related to the properties of crude oil, but also depended on the metal ions $\left(\mathrm{Mn}^{2+}, \mathrm{Sr}^{2+}, \mathrm{Br}^{-}\right)$and water content in crude oil (Gonçalves et al. 2010; Gonçalves et al. 2011; Shliomis and Morozov 1994).

With the combination of NPPD and traditional PPD, the synergistic effect of magnetic field and PPDs has rarely been investigated. In the present work, the synergistic modification effect of an alternating magnetic field and a developed NPPD (He et al. 2016; Huang et al. 2018; Huang et al. 2019) on waxy model oil is investigated. The yield stress of the waxy model oil is systematically characterized. Parameters as magnetic field intensity, frequency and temperature are considered, which aims to advance the understanding of synergistic modification methods in waxy oil fluidity improvement.

\section{Experimental materials and methods}

The waxy model oil is prepared by dissolving $10 \mathrm{wt} \%$ mixed wax (Daqing Refining \& Chemical Company) into the solvent oil D80 (ExxonMobil). The viscosity $\left(25{ }^{\circ} \mathrm{C}\right)$ of D80 is $2.09 \mathrm{~mm}^{2} / \mathrm{s}$, and density $\left(15^{\circ} \mathrm{C}\right)$ is
Table 1 Carbon distribution of D80 and mixed wax

\begin{tabular}{llll}
\hline $\begin{array}{l}\text { Carbon } \\
\text { distribution of } \\
\text { D80 }\end{array}$ & $\begin{array}{l}\text { Carbon } \\
\text { contents of } \\
\text { D80, } \%\end{array}$ & $\begin{array}{l}\text { Carbon distribu- } \\
\text { tion of mixed } \\
\text { wax }\end{array}$ & $\begin{array}{l}\text { Carbon contents } \\
\text { of mixed wax, \% }\end{array}$ \\
\hline 11 & 12.6 & 29 & 4.6 \\
& & 30 & 2.8 \\
12 & 31.5 & 31 & 6.0 \\
& & 32 & 11.4 \\
13 & 30.5 & 33 & 9.2 \\
& & 34 & 9.2 \\
14 & 31.6 & 36 & 9.3 \\
& & 37 & 8.9 \\
15 & 3.6 & 38 & 8.1 \\
& & 39 & 6.8 \\
& & 40 & 5.7 \\
\hline
\end{tabular}

Table 2 WAT of undoped/doped (200 mg/kg) waxy model oil

\begin{tabular}{llll}
\hline Samples & Waxy model oil & $\begin{array}{l}\text { Waxy model } \\
\text { oil +EVA }\end{array}$ & $\begin{array}{l}\text { Waxy model } \\
\text { oil + NPPD }\end{array}$ \\
\hline WAT, ${ }^{\circ} \mathrm{C}$ & 26.5 & 25.6 & 27.3 \\
\hline
\end{tabular}

$0.795 \mathrm{~g} / \mathrm{cm}^{3}$. Carbon distribution of oil and mixed wax is provided in Table 1. The NPPD used is developed by melting blending of EVA and montmorillonite, organic modified by hexadecyl trimethyl ammonium bromide (Qin et al. 2005). Details of NPPD used can be found in studies (He et al. 2016; Huang et al. 2018; Huang et al. 2019). NPPD is dissolved in diesel solvent at a concentration of $3 \%$ (mass fraction) under stirring for $30 \mathrm{~min}$ before added into waxy model oil.

Wax appearance temperature (WAT) of undoped/doped waxy model oil is measured with differential scanning calorimeter (TA2000). The measured WAT is shown in Table 2. Yield stress of waxy model oil under magnetic field is obtained by rheometer (TA, DHR-2). The MR module of rheometer consists of upper and lower cover assembly, and a cylindrical core surrounded by solenoid (Fig. 1). Firstly, heating the waxy model oil to $60{ }^{\circ} \mathrm{C}$ and keeping $2 \mathrm{~h}$; then, cooling to set temperature at $0.5^{\circ} \mathrm{C} /$ $\mathrm{min}$ and keeping for $30 \mathrm{~min}$. Finally, applying shear stress from 0 to $600 \mathrm{~Pa}$ at $5 \mathrm{~Pa} / \mathrm{min}$ under magnetic field and obtaining the stress-strain curves. Crystal morphology of waxy model oil treated with magnetic field $(0.3 \mathrm{~T}, 20 \mathrm{~Hz})$ is observed by microscope (BX51) at $15{ }^{\circ} \mathrm{C}$. 
(a)

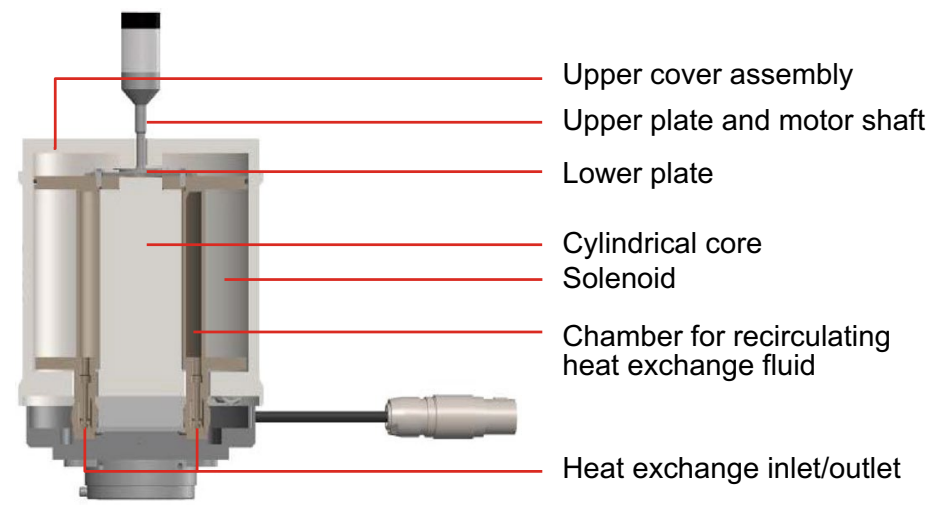

(b)

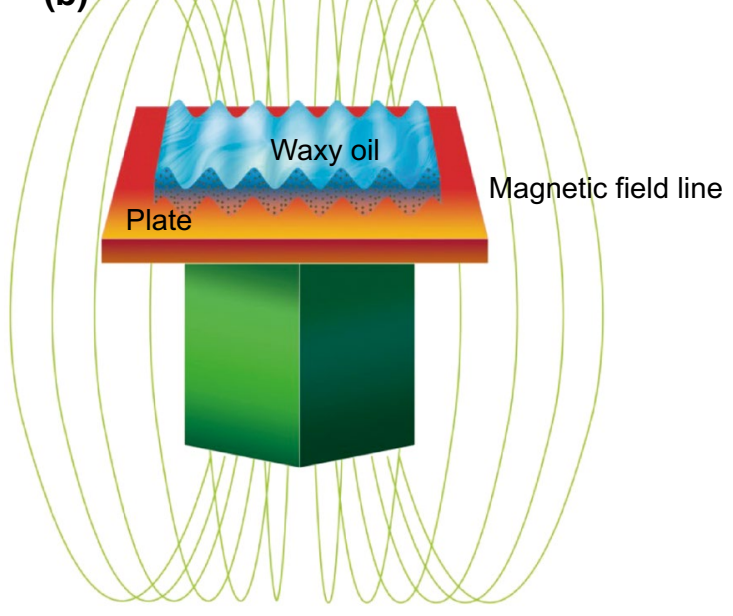

Fig. 1 MR module of rheometer, a structure diagram of MR module (TA Instruments-Waters LLC 2015), b schematic diagram of MR module

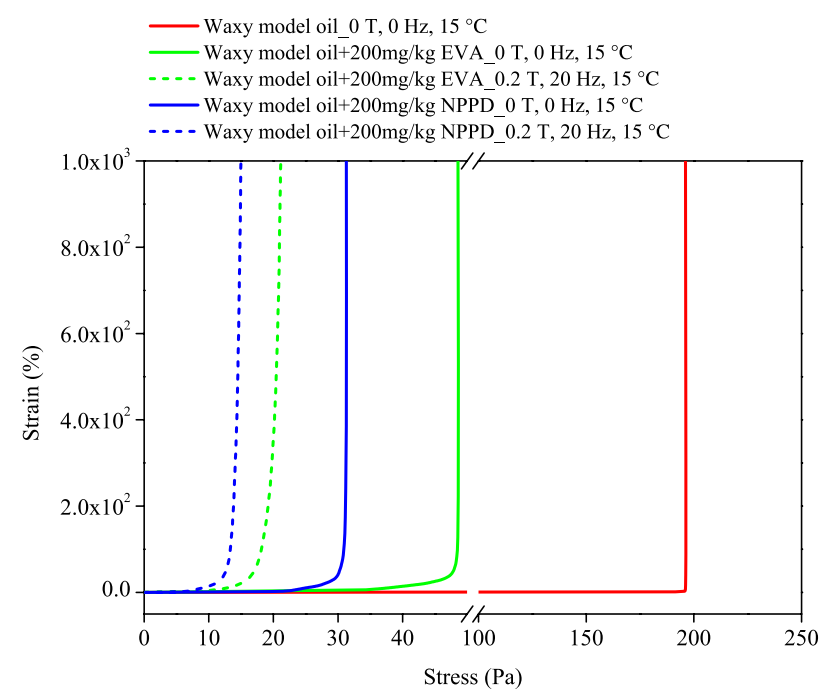

Fig. 2 Synergistic effect of magnetic field $(0.2 \mathrm{~T}, 20 \mathrm{~Hz})$ and EVA/ NPPD $(200 \mathrm{mg} / \mathrm{kg})$ on the yield stress of waxy model oil $\left(15^{\circ} \mathrm{C}\right)$

\section{Results and discussion}

To gain better understanding on the synergistic effect, an alternating magnetic field is applied to the NPPD-doped and EVA-doped waxy model oil. For example, combined with magnetic field $(0.2 \mathrm{~T}, 20 \mathrm{~Hz})$, the yield stress further decreases from 46 to $19 \mathrm{~Pa}$ (EVA doped) and 30 to $14 \mathrm{~Pa}$ (NPPD doped), as shown in Fig. 2. Factors influencing

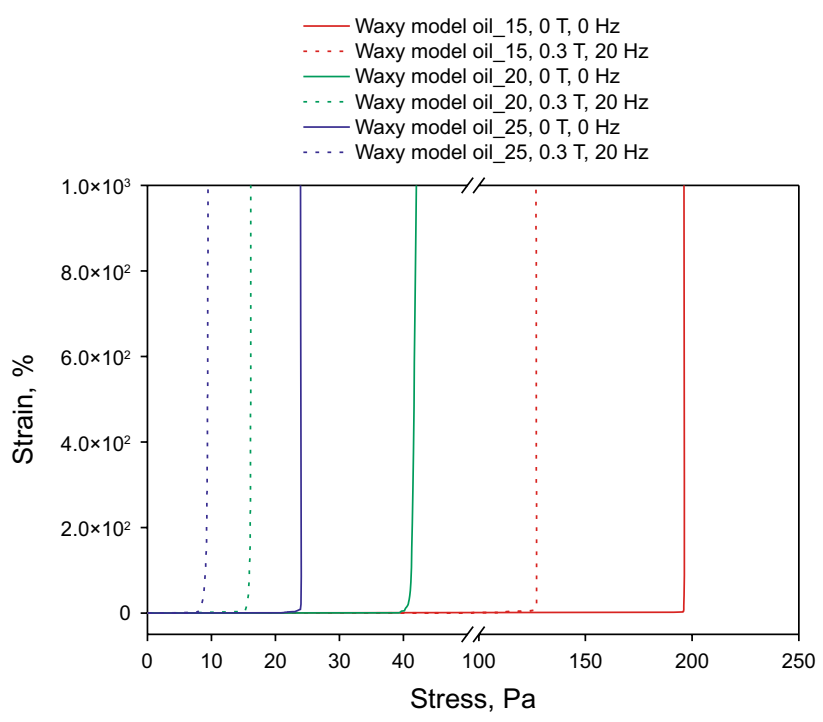

Fig. 3 Yield stress curves of undoped waxy model oil under magnetic field at different temperatures $\left(15,20,25^{\circ} \mathrm{C}\right)$

the synergistic modification of magnetic field and NPPD are systematically investigated.

\subsection{The synergistic modification effect under different temperatures}

When the temperature decreases to WAT, wax crystals precipitate and connect with each other. As a key parameter to characterize the strength of crystal network, the yield stress is temperature dependent (Venkatesan et al. 2005). The effect of magnetic field on yield stress under different 


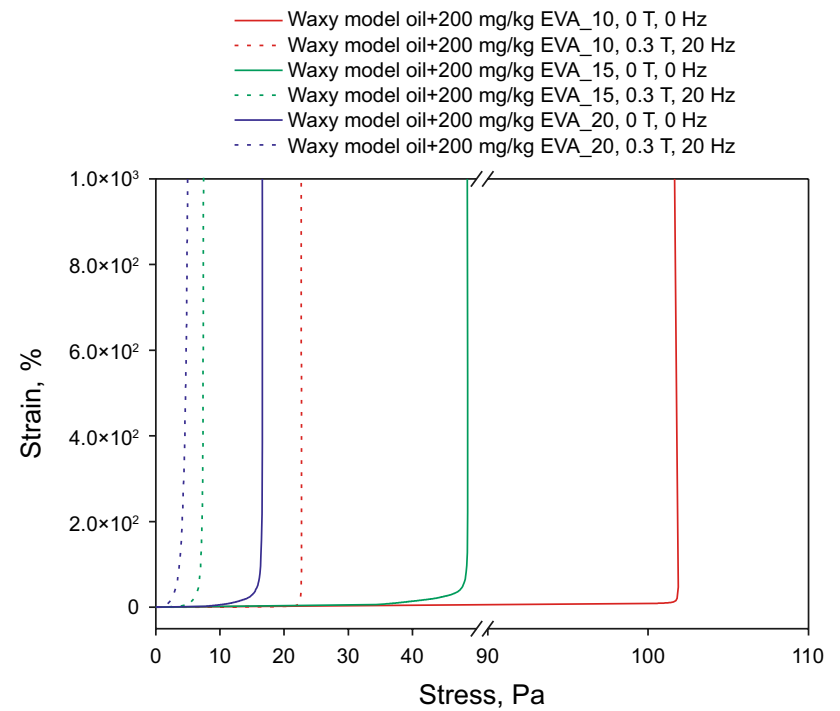

Fig. 4 Yield stress curves of EVA-doped ( $200 \mathrm{mg} / \mathrm{kg}$ ) waxy model oil under magnetic field at different temperatures $\left(10,15,20^{\circ} \mathrm{C}\right)$

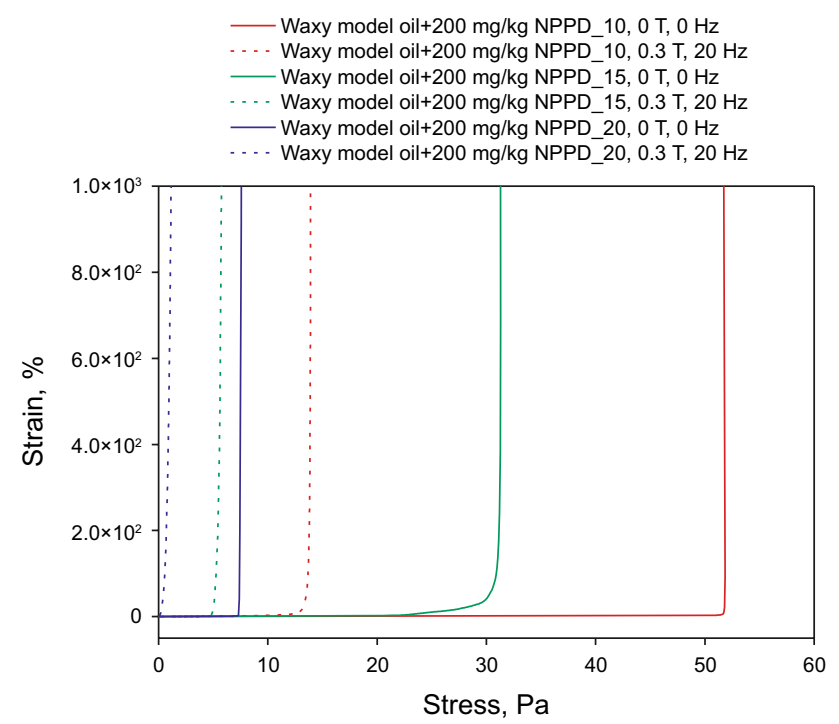

Fig. 5 Yield stress curves of NPPD-doped ( $200 \mathrm{mg} / \mathrm{kg}$ ) waxy model oil under magnetic field at different temperatures $\left(10,15,20^{\circ} \mathrm{C}\right)$

temperatures is important. An optimized magnetic field in current work $(0.3 \mathrm{~T}, 20 \mathrm{~Hz})$ is applied to the waxy model oil at different temperatures. The results of yield stress are shown in Figs. 3, 4 and 5.

For undoped waxy model oil, the yield stress without magnetic field is $196 \mathrm{~Pa}$ at $15^{\circ} \mathrm{C}$, while it decreases to $127 \mathrm{~Pa}(35.2 \%$ reduction) under magnetic field $(0.3 \mathrm{~T}$,
$20 \mathrm{~Hz}$ ), as shown in Fig. 3. At $20^{\circ} \mathrm{C}$, the yield stress without magnetic field is $41 \mathrm{~Pa}$, while the yield stress decreases to $16 \mathrm{~Pa}(60.9 \%$ reduction) under magnetic field. Similar trend is obtained at $25{ }^{\circ} \mathrm{C}$, where the yield stress varies from 24 to $9 \mathrm{~Pa}(62.5 \%$ reduction).

For doped waxy model oil, the yield stress at 20,15 and $10{ }^{\circ} \mathrm{C}$ is selected and compared as shown in Figs. 4 and $5\left(25^{\circ} \mathrm{C}\right.$ is not demonstrated due to a limited yield stress with PPD). For EVA-doped waxy model oil, the yield stress decreases from 16 to $4 \mathrm{~Pa}\left(20^{\circ} \mathrm{C}\right), 46$ to $8 \mathrm{~Pa}\left(15^{\circ} \mathrm{C}\right), 102$ to $23 \mathrm{~Pa}\left(10^{\circ} \mathrm{C}\right)$ under magnetic field $(0.3 \mathrm{~T}, 20 \mathrm{~Hz})$ in Fig. 4. The reduction in yield stress under magnetic field is $75 \%\left(20^{\circ} \mathrm{C}\right), 82.6 \%\left(15^{\circ} \mathrm{C}\right), 77.4 \%\left(10^{\circ} \mathrm{C}\right)$ under magnetic field. Similar effect is found in NPPD-doped waxy model oil; the yield stress decreases from 7 to $1 \mathrm{~Pa}\left(20^{\circ} \mathrm{C}\right), 30$ to $5 \mathrm{~Pa}\left(15^{\circ} \mathrm{C}\right), 50$ to $14 \mathrm{~Pa}\left(10^{\circ} \mathrm{C}\right)$ under magnetic field $(0.3 \mathrm{~T}, 20 \mathrm{~Hz})$ in Fig. 5. The reduction in yield stress is $85.7 \%\left(20^{\circ} \mathrm{C}\right), 83.3 \%\left(15^{\circ} \mathrm{C}\right), 72 \%\left(10^{\circ} \mathrm{C}\right)$ under magnetic field, as shown in Table 3.

The yield stress and its reduction are further compared at $15{ }^{\circ} \mathrm{C}$. It is found that the reduction in yield stress is $35.2 \%$ (196 to $127 \mathrm{~Pa}$ ) for undoped waxy model oil. However, with synergistic modification of NPPD or EVA and magnetic field, the reduction in yield stress is $83.3 \%$ (30 to $5 \mathrm{~Pa}$ ) for NPPD-doped and $82.6 \%$ (46 to $8 \mathrm{~Pa}$ ) for EVAdoped waxy model oil. The synergistic effect of magnetic field and NPPD is obviously compared to magnetic field alone. Furthermore, the synergistic effect under different magnetic intensities and frequencies is further investigated in Sects. 3.2 and 3.3.

\subsection{The effect of magnetic intensity on synergistic modification}

The effect of magnetic field intensity $(0-0.5 \mathrm{~T})$ on yield stress of waxy model oil is discussed at the magnetic field frequency of $20 \mathrm{~Hz}$. Based on Table 3, an intermittent temperature is selected for demonstration (undoped oil $20^{\circ} \mathrm{C}$, doped oil $\left.15{ }^{\circ} \mathrm{C}\right)$. For undoped oil $\left(20^{\circ} \mathrm{C}\right)$, the yield stress decreases from 41 to $37 \mathrm{~Pa}(0.1 \mathrm{~T}), 28 \mathrm{~Pa}(0.2 \mathrm{~T}), 16 \mathrm{~Pa}$ $(0.3 \mathrm{~T})$ and $5 \mathrm{~Pa}(0.4 \mathrm{~T})$, respectively. With the intensity further increasing to $0.5 \mathrm{~T}$, the yield stress slightly rebounds to $7 \mathrm{~Pa}$, as shown in Fig. 6 .

For EVA-doped oil $\left(200 \mathrm{mg} / \mathrm{kg}, 15^{\circ} \mathrm{C}\right)$, the yield stress is sensitive to the variation of magnetic field intensity which decreases from 46 to $25 \mathrm{~Pa}(0.1 \mathrm{~T}), 19 \mathrm{~Pa}$ $(0.2 \mathrm{~T}), 8 \mathrm{~Pa}(0.3 \mathrm{~T})$ and $5 \mathrm{~Pa}(0.4 \mathrm{~T})$. Similar trend is obtained that with the intensity increasing to $0.5 \mathrm{~T}$, the 
Table 3 Yield stress of wax model oil under magnetic field $(0.3 \mathrm{~T}, 20 \mathrm{~Hz})$

\begin{tabular}{|c|c|c|c|c|}
\hline \multirow[t]{2}{*}{ Samples } & \multirow[t]{2}{*}{ Temperature, ${ }^{\circ} \mathrm{C}$} & \multicolumn{2}{|l|}{ Yield stress, $\mathrm{Pa}$} & \multirow[t]{2}{*}{ Reduction, \% } \\
\hline & & Without magnetic & Magnetic field, $0.3 \mathrm{~T}, 20 \mathrm{~Hz}$ & \\
\hline \multirow[t]{3}{*}{ Undoped waxy model oil } & 15 & 196 & 127 & 35.2 \\
\hline & 20 & 41 & 16 & 60.9 \\
\hline & 25 & 24 & 9 & 62.5 \\
\hline \multirow[t]{3}{*}{ EVA-doped waxy model oil } & 10 & 102 & 23 & 77.4 \\
\hline & 15 & 46 & 8 & 82.6 \\
\hline & 20 & 16 & 4 & 75.0 \\
\hline \multirow[t]{3}{*}{ NPPD-doped waxy model oil } & 10 & 50 & 14 & 72.0 \\
\hline & 15 & 30 & 5 & 83.3 \\
\hline & 20 & 7 & 1 & 85.7 \\
\hline
\end{tabular}

Reduction $=100 \times($ yield stress without magnetic - yield stress under magnetic field $) /$ yield stress without magnetic

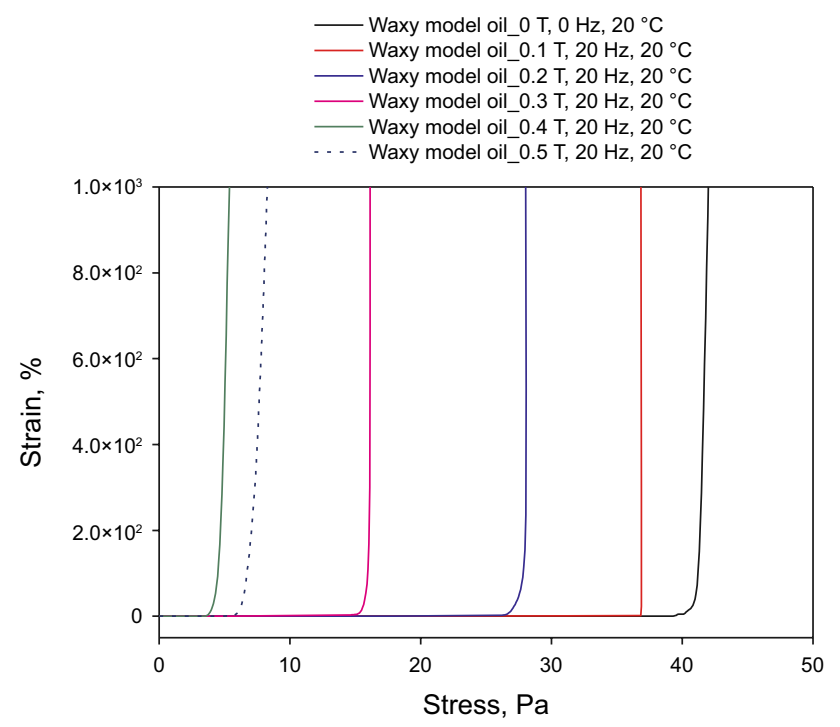

Fig. 6 Yield stress curves of undoped waxy model oil under magnetic field $\left(20 \mathrm{~Hz}, 20^{\circ} \mathrm{C}\right)$ at different intensities $(0-0.5 \mathrm{~T})$

yield stress increases to $9 \mathrm{~Pa}$ (Fig. 7). For NPPD-doped oil $\left(200 \mathrm{mg} / \mathrm{kg}, 15^{\circ} \mathrm{C}\right)$, the yield stress decreases from 30 to $27 \mathrm{~Pa}(0.1 \mathrm{~T}), 14 \mathrm{~Pa}(0.2 \mathrm{~T})$ and $5 \mathrm{~Pa}(0.3 \mathrm{~T})$. When the magnetic field intensity increases to 0.4 and $0.5 \mathrm{~T}$, the yield stress rebounds to $16 \mathrm{~Pa}$ and $20 \mathrm{~Pa}$ (Fig. 8).

Yield stress and its reduction in NPPD-/EVA-doped waxy model oil $\left(200 \mathrm{mg} / \mathrm{kg}, 20 \mathrm{~Hz}, 15^{\circ} \mathrm{C}\right)$ is further compared in Fig. 9; it can be gained that the optimal magnetic field intensity in EVA-doped oil is $0.4 \mathrm{~T}$, while it is $0.3 \mathrm{~T}$ in NPPD-doped oil.

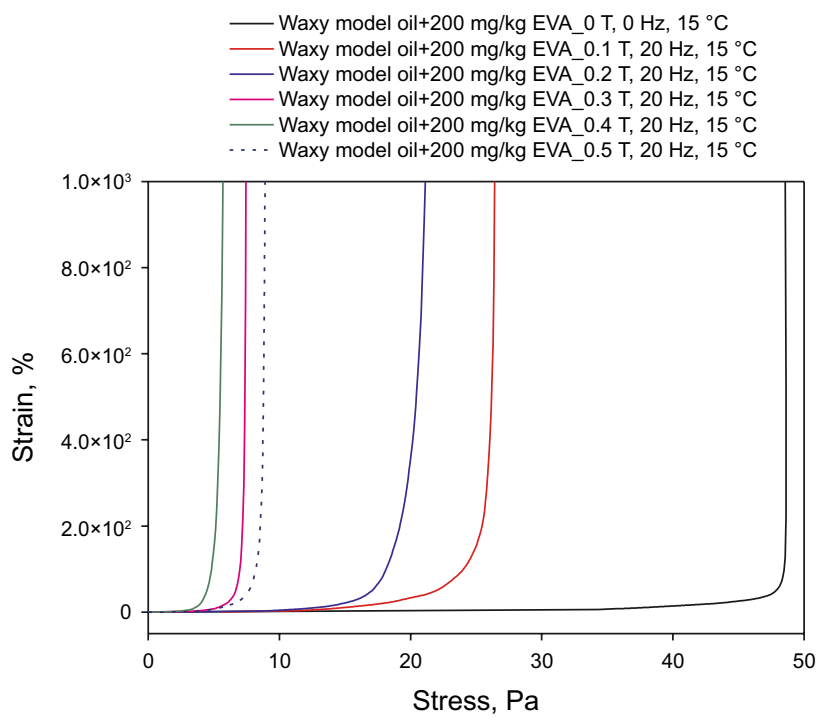

Fig. 7 Yield stress curves of EVA-doped $(200 \mathrm{mg} / \mathrm{kg})$ waxy model oil under magnetic field $\left(20 \mathrm{~Hz}, 15^{\circ} \mathrm{C}\right)$ at different intensities $(0-0.5 \mathrm{~T})$

\subsection{The effect of magnetic frequency on synergistic modification}

The effect of magnetic field frequency $(0-50 \mathrm{~Hz})$ on yield stress of waxy model oil is discussed at the magnetic field intensity of $0.3 \mathrm{~T}$. For undoped oil $\left(20^{\circ} \mathrm{C}\right)$, the yield stress decreases from 41 to $29 \mathrm{~Pa}(5 \mathrm{~Hz}), 24 \mathrm{~Pa}(10 \mathrm{~Hz}), 16 \mathrm{~Pa}$ $(20 \mathrm{~Hz})$ and $12 \mathrm{~Pa}(40 \mathrm{~Hz})$, respectively. However, an opposite trend is observed that the yield stress rebounds to $21 \mathrm{~Pa}$ 


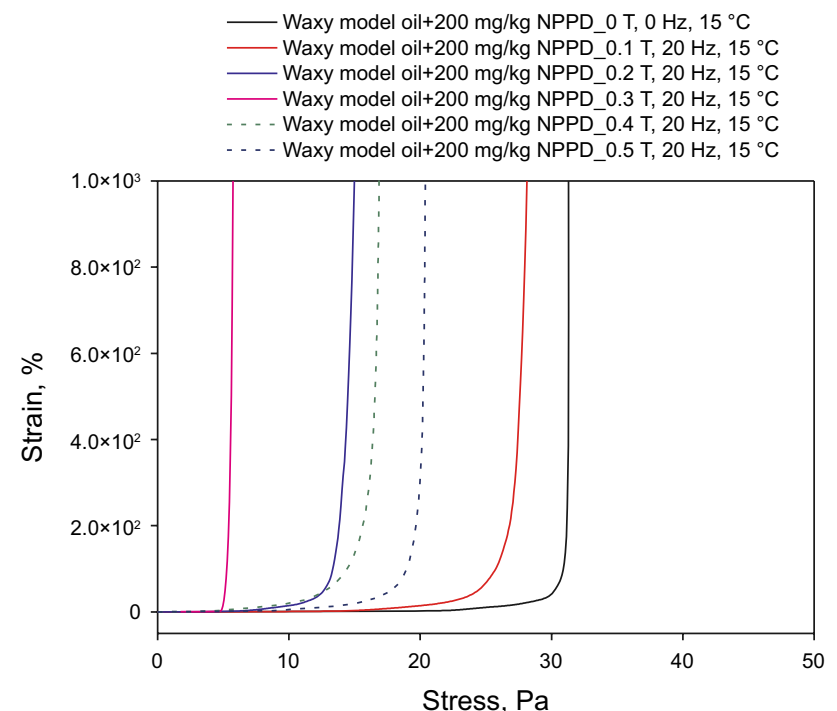

Fig. 8 Yield stress curves of NPPD-doped (200 mg/kg) waxy model oil under magnetic field $\left(20 \mathrm{~Hz}, 15^{\circ} \mathrm{C}\right)$ at different intensities $(0-0.5 \mathrm{~T})$

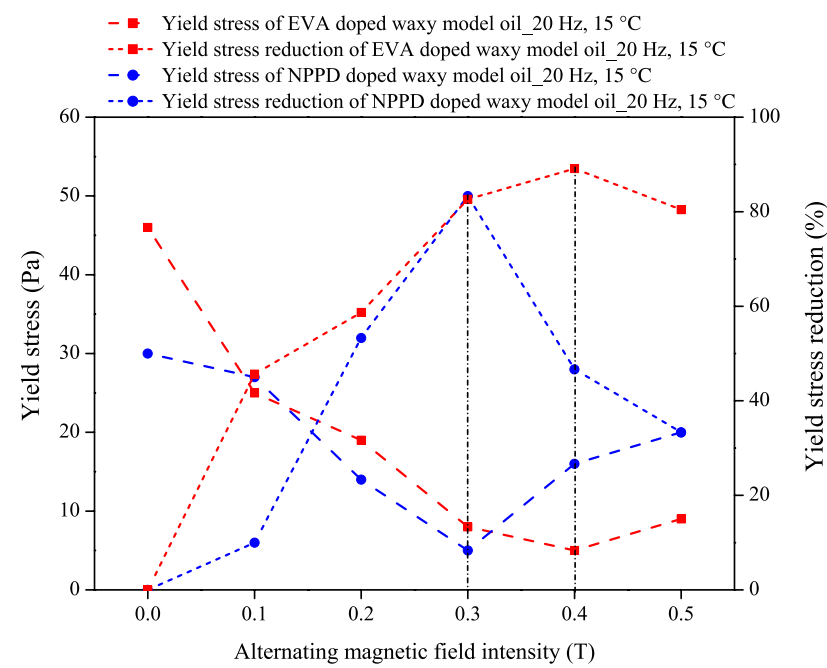

Fig. 9 Yield stress and its reduction in NPPD-/EVA-doped (200 mg/ $\mathrm{kg}$ ) waxy model oil under magnetic field $\left(20 \mathrm{~Hz}, 15^{\circ} \mathrm{C}\right)$ at different intensities $(0-0.5 \mathrm{~T})$

with the frequency further increasing to $50 \mathrm{~Hz}$, as shown in Fig. 10.

For EVA-doped oil $\left(200 \mathrm{mg} / \mathrm{kg}, 15^{\circ} \mathrm{C}\right)$, the yield stress decreases from 46 to $39 \mathrm{~Pa}(5 \mathrm{~Hz}), 15 \mathrm{~Pa}(10 \mathrm{~Hz})$ and $8 \mathrm{~Pa}$ $(20 \mathrm{~Hz})$. There is a minimum yield stress of $6 \mathrm{~Pa}(40 \mathrm{~Hz})$. Then the yield stress increases to $9 \mathrm{~Pa}$ with the frequency increasing to $50 \mathrm{~Hz}$ (Fig. 11). For NPPD-doped oil $\left(200 \mathrm{mg} / \mathrm{kg}, 15^{\circ} \mathrm{C}\right)$, the

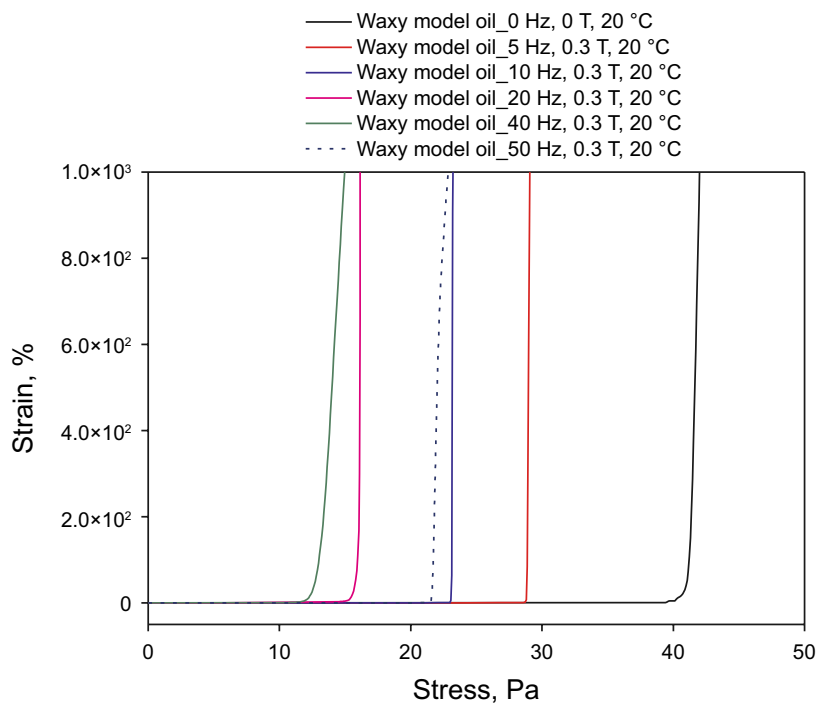

Fig. 10 Yield stress curves of undoped waxy model oil under magnetic field $\left(0.3 \mathrm{~T}, 20^{\circ} \mathrm{C}\right)$ at different frequencies $(0-50 \mathrm{~Hz})$

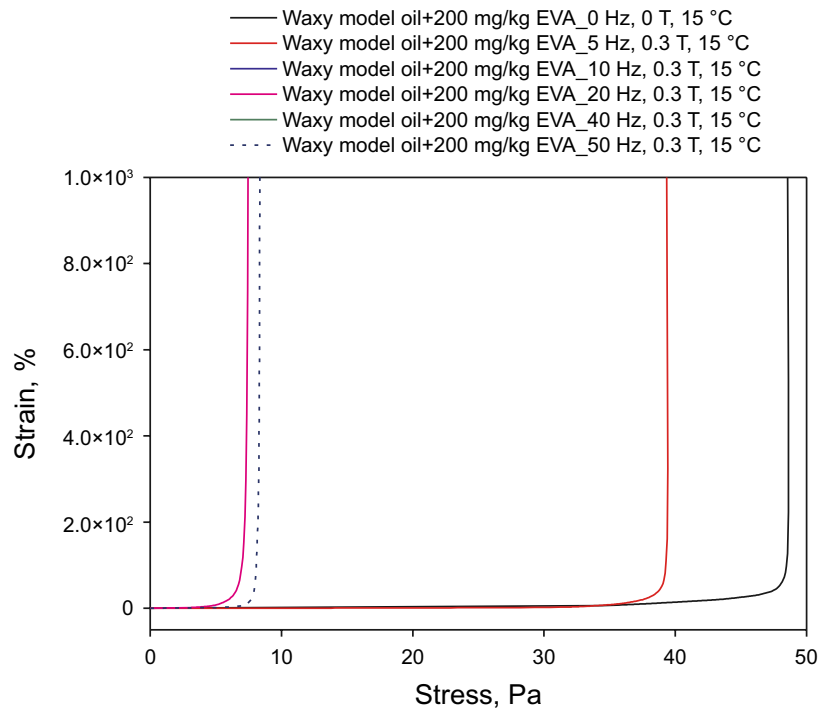

Fig. 11 Yield stress curves of EVA-doped ( $200 \mathrm{mg} / \mathrm{kg}$ ) waxy model oil under magnetic field $\left(0.3 \mathrm{~T}, 15^{\circ} \mathrm{C}\right)$ at different frequencies $(0-50 \mathrm{~Hz})$

yield stress decreases from 30 to $27 \mathrm{~Pa}(5 \mathrm{~Hz}), 24 \mathrm{~Pa}(10 \mathrm{~Hz})$ and $5 \mathrm{~Pa}(20 \mathrm{~Hz})$. An opposite trend is observed that the yield stress rebounds and increases to 15 and $25 \mathrm{~Pa}$ with the frequency increasing to 40 and $50 \mathrm{~Hz}$ (Fig. 12). 


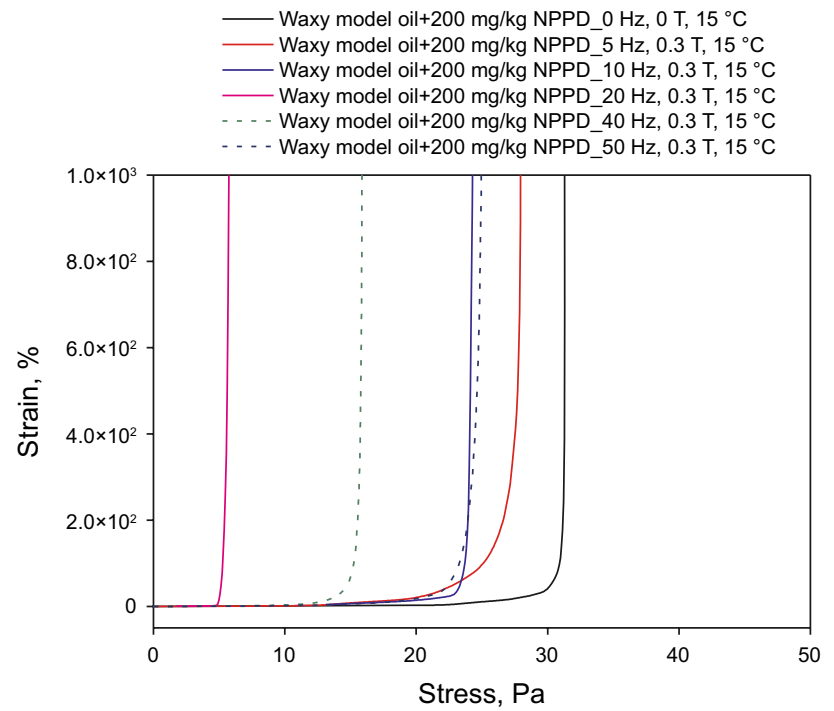

Fig. 12 Yield stress curves of NPPD-doped (200 mg/kg) waxy model oil under magnetic field $\left(0.3 \mathrm{~T}, 15^{\circ} \mathrm{C}\right)$ at different frequencies $(0-50 \mathrm{~Hz})$

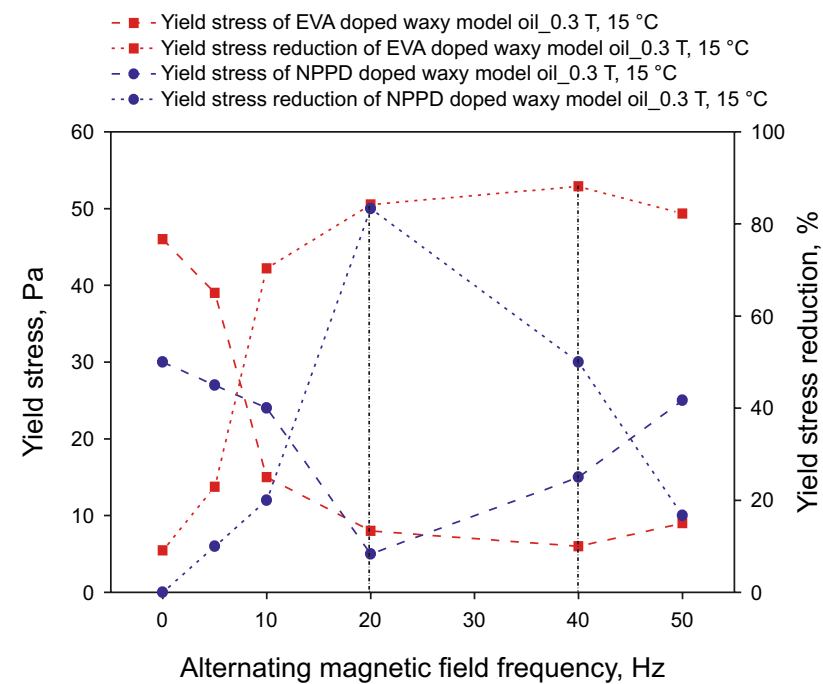

Fig. 13 Yield stress and its reduction in NPPD-/EVA-doped (200 mg/ $\mathrm{kg}$ ) waxy model oil under magnetic field $\left(0.3 \mathrm{~T}, 15^{\circ} \mathrm{C}\right)$ at different frequencies $(0-50 \mathrm{~Hz})$
Yield stress and its reduction in NPPD-/EVA-doped waxy model oil $\left(200 \mathrm{mg} / \mathrm{kg}, 0.3 \mathrm{~T}, 15^{\circ} \mathrm{C}\right)$ is further compared in Fig. 13. It can be gained that the optimal magnetic field frequency in EVA-doped oil is $40 \mathrm{~Hz}$, where the yield reduction is better than other frequencies, while the optimal magnetic field frequency in NPPD-doped oil is $20 \mathrm{~Hz}$ (Fig. 13).

Actually, yield stress behavior under different magnetic intensities and frequencies reflects the influence of magnetic field on wax crystal's network. As shown in Fig. 14a, the precipitated wax crystals obviously interacted with each other and formed network structure in undoped waxy model oil; the yield stress is $196 \mathrm{~Pa}$ at $15{ }^{\circ} \mathrm{C}$. With the addition of EVA (Fig. 14c) or NPPD (Fig. 14e), co-crystallization in EVA or heterogeneous nucleation in NPPD-doped system (He et al. 2016; Norrman et al. 2016) demonstrates the modification of crystal morphology; consequently, the yield stress is reduced to $46 \mathrm{~Pa}$ (EVA) and $30 \mathrm{~Pa}$ (NPPD) at $15^{\circ} \mathrm{C}$. It is interesting that an aggregation trend of wax crystals is observed after treated with magnetic field, which contributes to the release of liquid oil wrapped between crystal network (Ma et al. 2017; Tao et al. 2014). The change of wax crystal morphology under magnetic field results in a lower yield stress (undoped oil, $196 \mathrm{~Pa}$ to $127 \mathrm{~Pa}$; EVA-doped oil, $46 \mathrm{~Pa}$ to $8 \mathrm{~Pa}$; NPPD-doped oil, $30 \mathrm{~Pa}$ to $5 \mathrm{~Pa}$ ) (AlSabagh et al. 2016). However, when the optimum magnetic field is exceeded, aggregation of wax crystals might reversely strengthen the crystal network. (Fig. 15)

\section{Conclusions}

The effect of alternating magnetic field (intensity, frequency) on the yield stress of waxy model oil with/without PPDs is investigated. It is found that the optimum magnetic intensity is $0.4 \mathrm{~T}$ for EVA-doped oil and is $0.3 \mathrm{~T}$ for NPPD-doped oil. Furthermore, for magnetic frequency, the optimal value is $20 \mathrm{~Hz}$ for NPPD-doped system, but $40 \mathrm{~Hz}$ for EVAdoped system. When the magnetic intensity or frequency is lower than this optimum value, the yield stress reduction is enhanced with the increase in intensity and frequency. However, the modification is found to be weakened when the magnetic field is further increased after the optimal value. Under the magnetic field, the aggregation of wax crystals would be altered which could be owed to the variation of yield stress. 


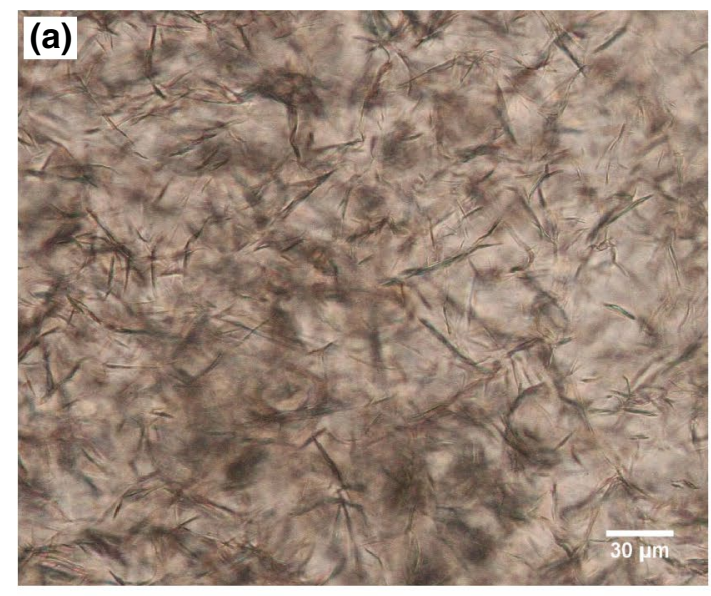

Undoped waxy oil

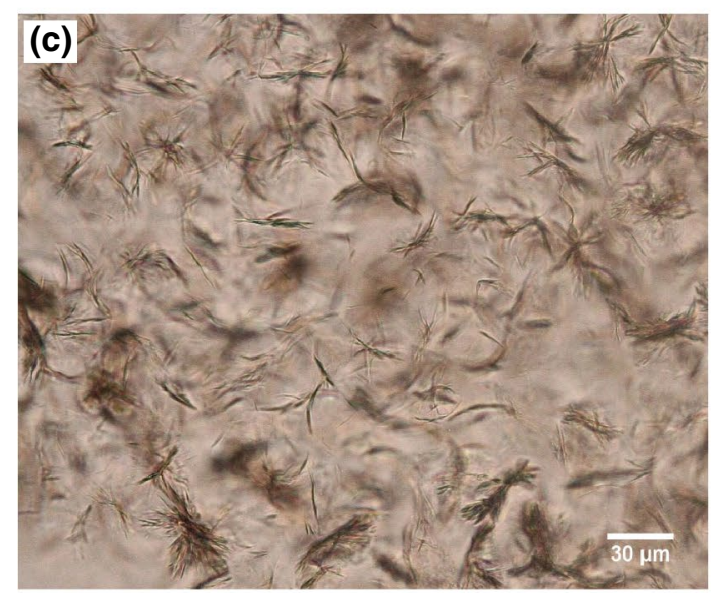

$200 \mathrm{mg} / \mathrm{kg}$ EVA doped waxy oil

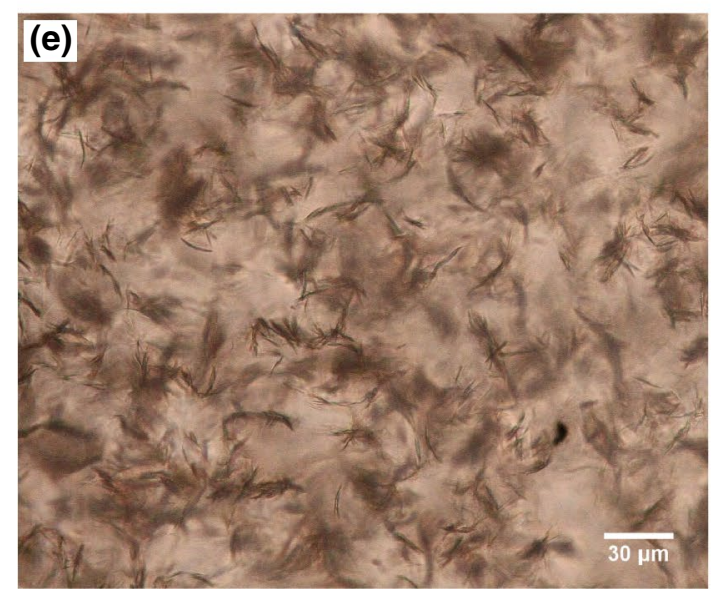

$200 \mathrm{mg} / \mathrm{kg}$ NPPD doped waxy oil

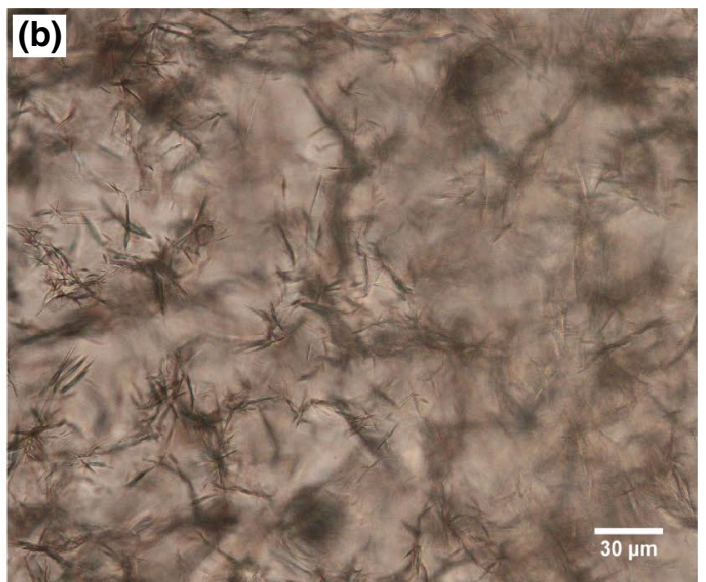

Undoped waxy oil with magnetic field $(0.3 \mathrm{~T}, 20 \mathrm{~Hz})$

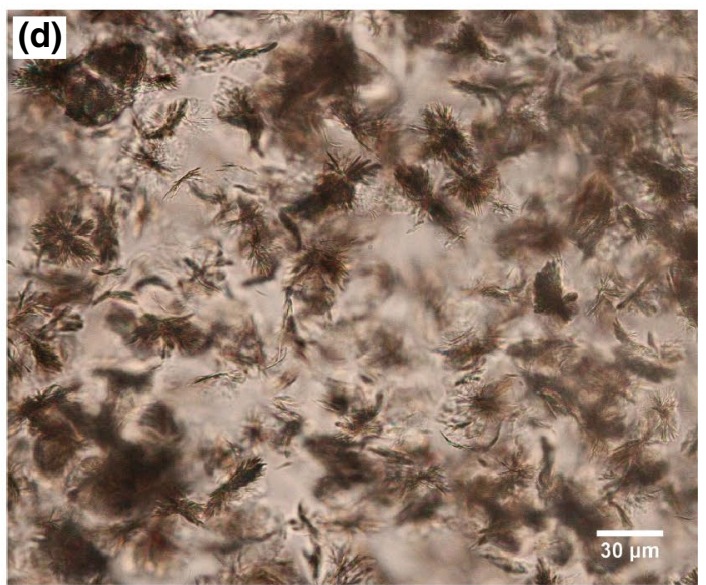

$200 \mathrm{mg} / \mathrm{kg}$ EVA doped waxy oil with magnetic field $(0.3 \mathrm{~T}, 2 \mathrm{~Hz})$

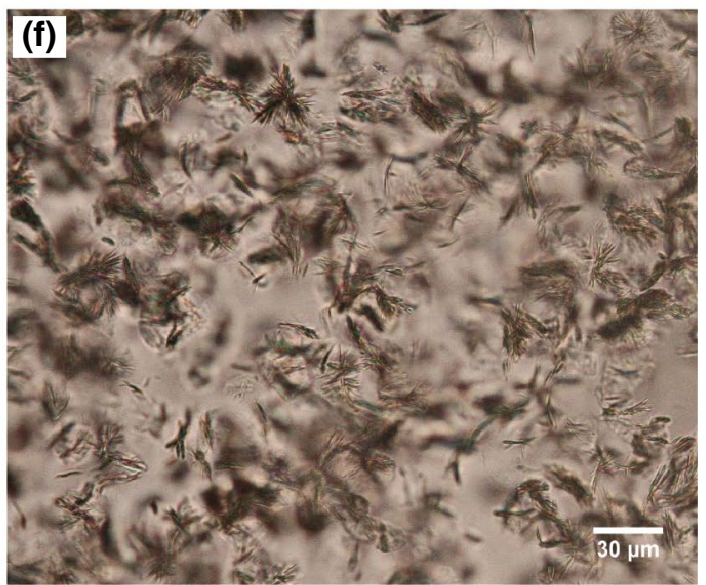

$200 \mathrm{mg} / \mathrm{kg}$ NPPD doped waxy oil with magnetic field $(0.3 \mathrm{~T}, 20 \mathrm{~Hz})$

Fig. 14 The morphology of undoped/doped waxy model oil with/without magnetic field $(0.3 \mathrm{~T}, 20 \mathrm{~Hz})$ 


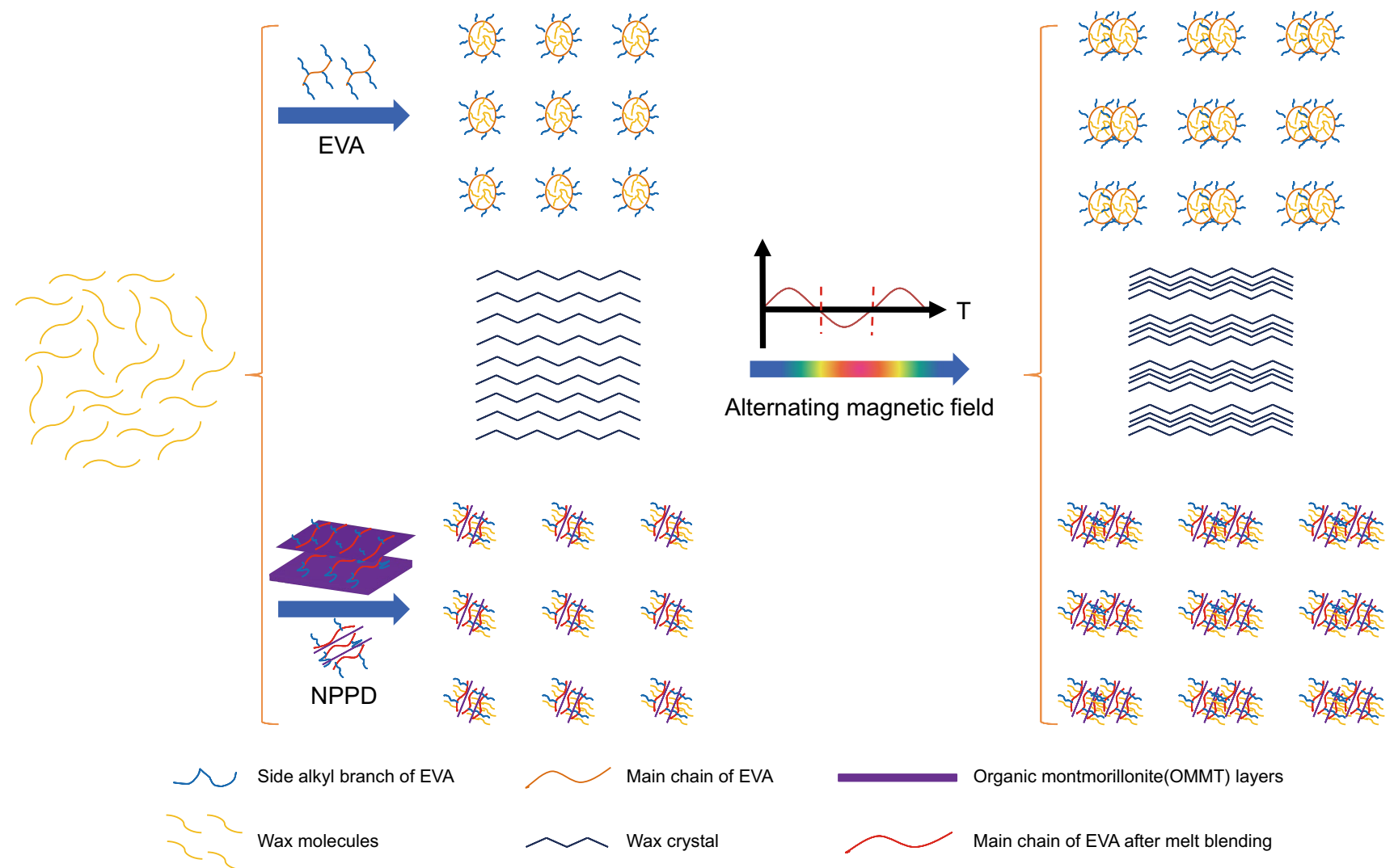

Fig. 15 The schematic diagram of synergistic modification

Acknowledgements The authors wish to thank the National Natural Science Foundation of China (51774303, 51422406, 51534007), the National Science \& Technology Specific Project (2016ZX05028-004001), 111 Project (B18054) and Science Foundation of China University of Petroleum, Beijing (C201602) for providing support for this work.

\section{Compliance with ethical standards}

Conflicts of interest There are no conflicts of interest to declare.

Open Access This article is licensed under a Creative Commons Attribution 4.0 International License, which permits use, sharing, adaptation, distribution and reproduction in any medium or format, as long as you give appropriate credit to the original author(s) and the source, provide a link to the Creative Commons licence, and indicate if changes were made. The images or other third party material in this article are included in the article's Creative Commons licence, unless indicated otherwise in a credit line to the material. If material is not included in the article's Creative Commons licence and your intended use is not permitted by statutory regulation or exceeds the permitted use, you will need to obtain permission directly from the copyright holder. To view a copy of this licence, visit http://creativecommons.org/licenses/by/4.0/.

\section{References}

Al-Sabagh AM, Betiha MA, Osman DI, Hashim AI, ElSukkary MM, Mahmoud T. A new covalent strategy for functionalized montmorillonite poly methyl methacrylate for improving the flowability of crude oil. J RSC Adv. 2016;6(111):109460-72. https://doi. org/10.1039/C6RA21319G.

Al-Sabagh AM, Betiha MA, Osman DI, Hashim AI, El-Sukkary MM, Mahmoud T. Preparation and evaluation of poly(methyl methacrylate)-graphene oxide nanohybrid polymers as pour point depressants and flow improvers for waxy crude oil. Energy Fuels. 2016;30(9):7610-21. https://doi.org/10.1021/acs.energ yfuels.6b01105.

Ashbaugh HS, Radulescu A, Prud'Homme RK, Schwahn D, Richter $\mathrm{D}$, Fetters LJ. Interaction of paraffin wax gels with random crystalline/amorphous hydrocarbon copolymers. Macromolecules. 2002;35(18):7044-53. https://doi.org/10.1021/ma0204047.

Bacri JC, Perzynski R, Shliomis MI, Burde GI. "Negative-viscosity" effect in a magnetic fluid. Phys Rev Lett. 1995;75(11):2128. https ://doi.org/10.1103/PhysRevLett.75.2128.

Bai J, Jin X, Wu JT. Multifunctional anti-wax coatings for paraffin control in oil pipelines. Pet Sci. 2019;16(3):619-31. https://doi. org/10.1007/s12182-019-0309-7.

Binks BP, Fletcher PDI, Roberts NA, Dunkerley J, Greenfield H, Mastrangelo A, et al. How polymer additives reduce the pour point of hydrocarbon solvents containing wax crystals. Phys Chemistry Chemical Physics. 2015;17(6):4107-17. https://doi.org/10.1039/ C4CP04329D. 
Castro LV, Vazquez F. Copolymers as flow improvers for Mexican crude oils. Energy Fuels. 2008;22(6):4006-11. https://doi. org/10.1021/ef800448a.

Castro LV, Vazquez F. Terpolymers as flow improvers for Mexican crude oils. Energy Fuels. 2011;25(2):539-44. https://doi. org/10.1021/ef101074m.

Chevallier V, Bouroukba M, Petitjean D, Dirand M, Pauly J, Daridon JL, Ruffier-Meray V. Crystallization of a multiparaffinic wax in normal tetradecane. Fuel. 2000;79(14):1743-50. https://doi. org/10.1016/S0016-2361(00)00036-3.

Deshmukh S, Bharambe DP. Synthesis of polymeric pour point depressants for Nada crude oil (Gujarat, India) and its impact on oil rheology. Fuel Process Technol. 2008;89(3):227-33. https://doi. org/10.1016/j.fuproc.2007.10.010.

Deshmukh S, Bharambe DP. The improvement of low temperature flow characteristics of waxy crude oil using multifunctional polymeric additives. Pet Sci Technol. 2014;32(11):1333-9. https://doi. org/10.1080/10916466.2012.655873.

Du E, Zhao Q, Xiao Y, Tao R. Reducing viscosity of ultra low sulfur diesel with electric field. Am J Aerosp Eng. 2018;5(1):56-62. https://doi.org/10.11648/j.ajae.20180501.18.

Ganeeva YM, Yusupova TN, Romanov GV. Waxes in asphaltenes of crude oils and wax deposits. Pet Sci. 2016;13(4):737-45. https:// doi.org/10.1007/s12182-016-0111-8.

Gao C, He C, Ding Y, Chen J, Wang F, Liu P et al. The yield stress of model waxy oil after incorporation of organic montmorillonite. Fuel. 2017;203:570-8. https://doi.org/10.1016/j.fuel.2017.05.011.

Gonçalves JL, Bombard AJF, Soares DAW, Alcantara GB. Reduction of paraffin precipitation and viscosity of Brazilian crude oil exposed to magnetic fields. Energy Fuels. 2010;24(5):3144-9. https://doi.org/10.1021/ef901302y.

Gonçalves JL, Bombard AJF, Soares DAW, Carvalho RD, Nascimento A, Silva MR, et al. Study of the factors responsible for the rheology change of a Brazilian crude oil under magnetic fields. Energy Fuels. 2011;25(8):3537-43. https://doi.org/10.1021/ef101740b.

Guo X, Pethica BA, Huang JS, Prud'Homme RK. Crystallization of long-chain n-paraffins from solutions and melts as observed by differential scanning calorimetry. Macromolecules. 2004;37(15):5638-45. https://doi.org/10.1021/ma035848x.

Hassanzadeh M, Tayebi L, Dezfouli H. Investigation of factors affecting on viscosity reduction of sludge from Iranian crude oil storage tanks. Pet Sci. 2018;15(3):634-43. https://doi.org/10.1007/s1218 2-018-0247-9.

He C, Ding Y, Chen J, Wang F, Gao C, Zhang S, Yang M. Influence of the nano-hybrid pour point depressant on flow properties of waxy crude oil. Fuel. 2016;167:40-8. https://doi.org/10.1016/j. fuel.2015.11.031.

Huang J, Xu J, Wang D, Li L, Guo X. Effects of amphiphilic copolymer dispersants on rheology and stability of coal water slurry. Ind Eng Chem Res. 2013;52(25):8427-35. https://doi.org/10.1021/ ie400681f.

Huang H, Wang W, Peng Z, Ding Y, Li K, Li Q et al. The influence of nanocomposite pour point depressant on the crystallization of waxy oil. Fuel. 2018;221:257-68. https://doi.org/10.1016/j. fuel.2018.01.040.

Huang H, Wang W, Peng Z, Li K, Gan D, Zhang S, et al. The effect of cooling processes on the yield stress of waxy model oil with nanocomposite pour point depressant. J Pet Sci Eng. 2019;175:828-37. https://doi.org/10.1016/j.petrol.2018.12.084.

Xu J, Qian HQ, Xing SL, Li L, Guo XH. Synthesis of poly (maleic acid alkylamide-co- $\alpha$-olefin-co-styrene) co-polymers and their effect on the yield stress and morphology of waxy gels with asphaltenes. Energy Fuels. 2010;25(2):573-9. https://doi.org/10.1021/ef101 2215.
Li L, Xu J, Tinsley J, Adamson DH. Improvement of oil flowability by assembly of comb-type copolymers with paraffin and asphaltene. AIChE J. 2012;58(7):2254-61. https://doi.org/10.1002/aic.12729.

Li Y, Han S, Lu Y, Zhang J. Influence of asphaltene polarity on crystallization and gelation of waxy oils. Energy Fuels. 2018;32(2):1491-7. https://doi.org/10.1021/acs.energyfuel s.7b03553.

Lim ZH, Al Salim HS, Ridzuan N, Nguele R, Sasaki K. Effect of surfactants and their blend with silica nanoparticles on wax deposition in a Malaysian crude oil. Pet Sci. 2018;15(3):577-90. https ://doi.org/10.1007/s12182-018-0241-2.

Liu T, Fang L, Liu X, Zhang X. Preparation of a kind of reactive pour point depressant and its action mechanism. Fuel. 2015;143:44854. https://doi.org/10.1016/j.fuel.2014.11.094.

Ma C, Lu Y, Chen C, Feng K, Li Z, Wang X, et al. Electrical treatment of waxy crude oil to improve its cold flowability. Ind Eng Chem Res. 2017;56(38):10920-8. https://doi.org/10.1021/acs. iecr.7b02140.

Martínez-Palou R, de Lourdes Mosqueira M, Zapata-Rendón B, Mar-Juárez E, Bernal-Huicochea C, de la Cruz Clavel-López J, et al. Transportation of heavy and extra-heavy crude oil by pipeline: a review. J Pet Sci Eng. 2011;75(3-4):274-82. https://doi. org/10.1016/j.petrol.2010.11.020.

Norrman J, Solberg A, Sjöblom J, Paso K. Nanoparticles for waxy crudes: effect of polymer coverage and the effect on wax crystallization. Energy Fuels. 2016;30(6):5108-14. https://doi. org/10.1021/acs.energyfuels.6b00286.

Pechook S, Katsman A, Pokroy B. Paraffin wax crystal coarsening: effects of strain and wax crystal shape. Cryst Growth Des. 2016;16(7):3932-9. https://doi.org/10.1021/acs.cgd.6b00499.

Qin HL, Zhang SM, Liu HJ, Xie SB, Yang MS, Shen DY. Photo-oxidative degradation of polypropylene/montmorillonite nanocomposites. Polymer. 2005;46(9):3149-56. https://doi.org/10.1016/j. polymer.2005.01.087.

Rosensweig RE. "Negative viscosity" in a magnetic fluid. Science. 1996;271(5249):614-5. https://doi.org/10.1126/scien ce.271.5249.614.

Shliomis MI, Morozov KI. Negative viscosity of ferrofluid under alternating magnetic field. Phys Fluids. 1994;6(8):2855-61. https:// doi.org/10.1063/1.868108.

Song X, Yin $\mathrm{H}$, Feng Y, Zhang S, Wang Y. Effect of $\mathrm{SiO}_{2}$ nanoparticles on wax crystallization and flow behavior of model crude oil. Ind Eng Chem Res. 2016;55(23):6563-8. https://doi.org/10.1021/acs. iecr.6b00836.

Soni HP, Kiranbala, Bharambe DP. Performance-based designing of wax crystal growth inhibitors. Energy Fuels. 2008;22(6):3930-8. https://doi.org/10.1021/ef8002763.

Soni HP, Kiranbala, Agrawal KS, Nagar A, Bharambe DP. Designing maleic anhydride- $\alpha$-olifin copolymeric combs as wax crystal growth nucleators. Fuel Process Technol. 2010;91(9):997-1004. https://doi.org/10.1016/j.fuproc.2010.02.019.

TA Instruments-Waters LLC. DHR MagnetoRheology Getting Started Guide[R]. New Castle: 2015.

Tao R, Xu X. Reducing the viscosity of crude oil by pulsed electric or magnetic field. Energy Fuels. 2006;20(5):2046-51. https://doi. org/10.1021/ef060072x.

Tao R, Du E, Tang H, Xu X. Neutron scattering studies of crude oil viscosity reduction with electric field. Fuel. 2014;134:493-8. https ://doi.org/10.1016/j.fuel.2014.06.018.

Tu Z, Jing G, Sun Z, Zhen Z, Li W. Effect of nanocomposite of attapulgite/EVA on flow behavior and wax crystallization of model oil. J Dispersion Sci Technol. 2018;39(9):1280-4. https://doi. org/10.1080/01932691.2017.1394197.

Venkatesan R, Nagarajan NR, Paso K, Yi YB, Sastry AM, Fogler HS. The strength of paraffin gels formed under static and flow 
conditions. Chem Eng Sci. 2005;60(13):3587-98. https://doi. org/10.1016/j.ces.2005.02.045.

Visintin RFG, Lapasin R, Vignati E, D’Antona P, Lockhart TP. Rheological behavior and structural interpretation of waxy crude oil gels. Langmuir. 2005;21(14):6240-9. https://doi.org/10.1021/ la050705k.

Wang Z, Yu J, Zhang J, Liu S, Gao Y, Xiang H, et al. Improved thermal model considering hydrate formation and deposition in gasdominated systems with free water. Fuel, 2019;236:870-9. https ://doi.org/10.1016/j.fuel.2018.09.066.

Xu J, Xing S, Qian H, Chen S, Wei X, Zhang R, et al. Effect of polar/ nonpolar groups in comb-type copolymers on cold flowability and paraffin crystallization of waxy oils. Fuel. 2013;103:600-5. https ://doi.org/10.1016/j.fuel.2012.06.027.

Yang F, Yao B, Li C, Sun G, Ma X. Oil dispersible polymethylsilsesquioxane (PMSQ) microspheres improve the flow behavior of waxy crude oil through spacial hindrance effect. Fuel. 2017;199:4-13. https://doi.org/10.1016/j.fuel.2017.02.062.
Yang J, Wang W, Shi G, Wang D, Gong J, Shi B, et al. Predicting solidliquid-vapor equilibria in highly asymmetric paraffinic systems with EOS-GE model. Fluid Phase Equilibria. 2019;480:1-10. https://doi.org/10.1016/j.fluid.2018.10.003.

Yao B, Li C, Zhang X, Yang F, Sun G, Zhao Y. Performance improvement of the ethylene-vinyl acetate copolymer (EVA) pour point depressant by small dosage of the amino-functionalized polymethylsilsesquioxane (PAMSQ) microsphere. Fuel. 2018;220:16776. https://doi.org/10.1016/j.fuel.2018.01.032.

Zhang J, Yu B, Li H, Huang Q. Advances in rheology and flow assurance studies of waxy crude. Pet Sci. 2013;10(4):538-47. https:// doi.org/10.1007/s12182-013-0305-2.

Zhao Z, Yan S, Lian J, Chang W, Xue Y, He Z, et al. A new kind of nanohybrid poly (tetradecyl methyl-acrylate)-graphene oxide as pour point depressant to evaluate the cold flow properties and exhaust gas emissions of diesel fuels. Fuel. 2018;216:818-25. https://doi.org/10.1016/j.fuel.2017.07.087. 